Dapat diakses pada: http://jkb.ub.ac.id/index.php/jkb/article/view/1852

Jurnal Kedokteran Brawijaya Vol. 29, No. 04, Agustus 2017, pp. 329-334

Online Published First: 31 Agustus 2017

Article History: Received 10 Oktober 2016, Accepted 10 Juni 2017

Artikel Penelitian

\title{
Hubungan Polimorfisme Gen ACTN3 dengan Kelincahan, Daya Ledak, dan Kecepatan
}

\section{The Relationship of ACTN3 Gene Polymorphisms with Agility, Explosive Power, and Speed}

\author{
Susiana Candrawati ${ }^{1}$, Nur Signa $A G^{2}$, Muhammad Nanang $H K^{3}$, Pradani Eva $A^{3}$, Muhammad Cahya $\mathrm{RS}^{3}$, \\ Sarah Shafira $A R^{3}$ \\ ${ }^{1}$ Laboratorium Fisiologi Kedokteran Fakultas Kedokteran Universitas Jenderal Soedirman Purwokerto \\ ${ }^{2}$ Laboratorium Histologi Kedokteran Fakultas Kedokteran Universitas Jenderal Soedirman Purwokerto \\ ${ }^{3}$ Fakultas Kedokteran Universitas Jenderal Soedirman Purwokerto
}

\begin{abstract}
ABSTRAK
Komponen biomotorik kelincahan, daya ledak, dan kecepatan merupakan komponen yang harus dimiliki atlet sepak bola. Penelusuran genetik dapat menjadi salah satu metode talent profiling pada atlet sepak bola. Talent profiling belum pernah dilakukan pada kalangan atlet Indonesia terutama atlet yunior seperti atlet Unit Kegiatan Mahasiswa (UKM) Sepak Bola di (Universitas Jenderal Soedirman) UNSOED. Salah satu gen yang berhubungan dengan performa adalah gen ACTN3. Gen ACTN3 yang merupakan gen pengkode protein $\alpha$-aktinin-3 pada serabut otot tipe cepat, diduga berpengaruh terhadap kelincahan, daya ledak dan kecepatan. Tujuan penelitian ini adalah untuk mengetahui hubungan polimorfisme gen ACTN3 dengan kelincahan, daya ledak dan kecepatan otot pada atlet sepakbola. Penelitian ini menggunakan rancangan studi observasional analitik dengan pendekatan cross sectional. Metode pengumpulan subjek pada penelitian ini menggunakan consecutive sampling. Subjek pada penelitian ini adalah 82 atlet yang mengikuti UKM sepak bola Universitas Jenderal Soedirman. Metode PCR-RFLP dan elektroforesis digunakan untuk melihat polimorfisme gen ACTN3. Sedangkan pengukuran komponen biomotorik menggunakan tes agilitas Illinois (kelincahan), jump meter digital (daya ledak) dan tes sprint 30 meter (kecepatan). Analisis data menggunakan uji ANOVA satu arah dengan tingkat kemaknaan $p=0,05$. Terdapat hubungan bermakna antara polimorfisme gen ACTN3 dengan daya ledak otot $(p=0,027)$ dan tidak terdapat hubungan bermakna antara polimorfisme gen ACTN 3 dengan kelincahan $(p=0,084)$ dan kecepatan $(p=0,507)$. Rerata terbaik ketiga komponen biomotorik terdapat pada alel RR gen ACTN 3. Disimpulkan terdapat hubungan antara polimorfisme gen ACTN3 dengan daya ledak otot, tapi tidak terdapat hubungan antara polimorfisme gen ACTN 3 dengan kelincahan dan kecepatan pada atlet sepakbola.
\end{abstract}

Kata Kunci: Daya ledak, kecepatan, kelincahan, polimorfisme gen ACTN3, sepak bola

\begin{abstract}
Agility, explosive power, and speed are biomotoric components that must be owned by soccer athletes. Genetic tracking can be one of the talent profiling methods on soccer athletes. Talent profiling has not been conducted in Indonesia, especially among junior athletes such as the athletes of Soccer Student Activity Unit in Universitas Jenderal Soedirman (UNSOED). One of the genes associated with performance is ACTN3 gene. ACTN 3 gene is a gene encoding alpha-actinin-3 protein in fast-twitch skeletal muscle fibers and may affect the agility, explosive power and speed. The aim of this study is to investigate the association of ACTN3 gene polymorphism with agility, explosive power, and speed of soccer athletes. This research used analytic observational study design with cross sectional approach. The subject collecting method in this study was using consecutive sampling. PCR-RFLP and electrophoresis methods were used to identify ACTN3 gene polymorphisms, while biomotor component were measured using Illinois agility test (agility), digital jump meter (explosive power) and 30-meter sprint test (speed). Data analysis was using one way ANOVA test with significance level $p=0,05$. There was significant association between ACTN3 gene polymorphism with explosive power $(p=0,027)$, but there was no significant association between ACTN3 gene polymorphism with agility $(p=0,084)$ and speed $(p=0,507)$. The best mean of the three biomotoric components was in RR alleles ACTN3 gene. It is concluded that there is an association of ACTN3 polymorphism with explosive power, but there is no association with agility and speed on the football athletes.
\end{abstract}

Keywords: ACTN3 gene polymorphism, agility, explosive power, soccer, speed

Korespondensi: Susiana Candrawati. Laboratorium Fisiologi Kedokteran Fakultas Kedokteran Universitas Jenderal Soedirman Purwokerto, Jl.DrGumbreg No. 1 Purwokerto Tel. (0281)641522 E-mail: susianacandrawati@gmail.com

DOI: http://dx.doi.org/10.21776/ub.jkb.2017.029.04.8 


\section{PENDAHULUAN}

Sepak bola merupakan salah satu cabang olahraga yang sangat populer dan paling sering dimainkan di seluruh dunia termasuk di Indonesia. Tetapi sayangnya hingga kini atlet sepak bola Indonesia belum mampu menorehkan prestasi yang membanggakan. Dari data Federation Internationale de Football Association (FIFA) pada tahun 2013 (1), Indonesia tercatat menduduki peringkat ke-168 dalam rangking persepakbolaan dunia. Dengan jumlah atlet sepak bola sebanyak 7.094.260 orang yang tersebar di seluruh Indonesia, hal ini tentu memunculkan pertanyaan mengapa prestasi Indonesia di kancah persepakbolaan dunia masih terbilang rendah meski jumlah atlet sepak bola yang ada tergolong banyak.

Kondisi fisik terkait komponen biomotorik merupakan salah satu faktor penting untuk mencapai prestasi. Pada cabang olahraga sepak bola komponen biomotorik yang berperan dominan dalam performa adalah kelincahan. Kelincahan adalah kemampuan seseorang untuk mengubah arah dan posisi tubuh dengan cepat dalam keadaan bergerak, tanpa kehilangan keseimbangan (2). Permainan sepak bola memerlukan unsur kelincahan saat atlet menggiring bola dan berlari cepat (sprint). Kelincahan melibatkan beberapa unsur biomotorik seperti daya ledak dan kecepatan (2). Daya ledak otot maksimal hanya akan dicapai pada saat kekuatan dan kecepatan maksimal bertemu dalam satu titik (3). Kecepatan sendiri merupakan salah satu komponen biomorik dasar selain kekuatan dan ketahanan (4). Sehingga komponen biomotorik kelincahan, daya ledak dan kecepatan merupakan komponen yang harus ada pada atlet sepak bola.

Komponen biomotorik yang berujung pada performa atletik setiap individu dipengaruhi oleh berbagai faktor diantaranya pola diet, pola latihan fisik dan faktor genetik (5). Faktor genetik menentukan $20-80 \%$ variasi sifat yang berkaitan dengan performa atletik (6). Penelusuran genetik dapat menjadi salah satu metode talent profiling pada atlet sepak bola. Salah satu gen yang berhubungan dengan performa atletik adalah gen ACTN3. Gen ACTN3 mengalami polimorfisme dimana terjadi perubahan nukleotida cytosine menjadi thymin di lokasi ekson 16 yang menghasilkan mutasi arginin menjadi premature stop kodon (X) di asam amino (R577X)(7). Variasi R577X menghasilkan dua variasi gen ACTN3 yaitu satu alel $R$ fungsional dan alel $X$ non fungsional dimana alel 577R (genotip 577R) diduga mempengaruhi kelincahan, daya ledak otot dan kecepatan pada performa atletik (8). Alel 577R memiliki kapasitas untuk kontraksi otot yang kuat dan cepat lebih tinggi dibandingkan alel 577X. Hal ini disebabkan persentase dan jumlah serabut otot tipe IIx (serabut otot glikolitik cepat) lebih banyak di genotip RR dibandingkan pada genotip XX. Sedangkan alel 577X mengalami defisiensi protein $\alpha$-aktinin- 3 yang menyebabkan perubahan metabolisme otot cepat menjadi jalur aerobik dikarenakan adanya kompensasi protein $\alpha$-aktinin-2 sehingga meningkatkan performa ketahanan otot pada atlet (9). Gen ACTN3 merupakan gen yang mengkode protein $\alpha$-aktinin-3, suatu protein sarkomer yang secara eksklusif diekspresikan di serabut otot tipe cepat khususnya pada lempeng Z myofibril yang penting sekali untuk memproduksi kontraksi otot yang kuat dan cepat (10). Selain itu, Alel 577R juga diduga mempunyai proteksi yang lebih terhadap kerusakan otot akibat kontraksi otot berulang dibandingkan alell yang lain
(11). Adanya protein $\alpha$-aktinin-3 yang khusus pada serabut otot rangka tipe cepat memberikan kapasitas yang lebih besar untuk absorpsi kekuatan ke lempeng $Z$ selama kontraksi sehingga meningkatkan pembentukan kedutan serabut otot tipe cepat dimana mempengaruhi keincahan, daya ledak dan kecepatan otot seseorang $(12,13)$. Informasi mengenai gen ACTN3 terhadap komponen biomotorik seperti kelincahan, daya ledak otot maupun kecepatan masih sangat terbatas sehingga peneliti tertarik untuk melihat apakah terdapat hubungan antara polimorfisme gen ACTN3 dengan kelincahan, daya ledak otot dan kecepatan pada atlet sepak bola.

\section{METODE}

Penelitian ini menggunakan metode studi observasional analitik dengan pendekatan cross sectional. Populasi target pada penelitian ini adalah atlet sepak bola, sedangkan populasi terjangkaunya adalah atlet UKM sepak bola Universitas Jenderal Soedirman. Subjek penelitian berjumlah 82 orang yang telah memenuhi kriteria pemilihan subjek penelitian. Kriteria pemilihan subjek penelitian diantaranya adalah berusia 18-24 tahun; berjenis kelamin laki laki; sehat dan layak melakukan tes komponen biomotorik (skrining dengan Physical Activity Readiness Questionnairre/PAR-Q); dan bersedia menjadi subjek penelitian yang dibuktikan dengan Informed Consent. Variabel bebas pada penelitian ini adalah polimorfisme gen ACTN3 dengan skala nominal (RR; RX; $X X)$, sedangkan variabel tergantungnya adalah komponen biomotorik yang terdiri dari kelincahan (skala rasio), daya ledak otot (skala rasio) dan kecepatan (skala rasio). Pengambilan darah subjek penelitian dan pemeriksaan polimorfisme gen ACTN 3 (isolasi DNA dan PCR-RFLP) dilakukan di Laboratorium Biokimia Jurusan Kedokteran Unsoed dan Laboratorium Riset Unsoed Purwokerto, sedangkan pengambilan data komponen biomotorik subjek penelitian dilaksanakan di Stadion Soesilo Soedarman Unsoed. Penelitian dilaksanakan dari bulan September 2013 sampai bulan Maret 2014.

\section{Pemeriksaan Komponen Biomotorik}

Pemeriksaan kelincahan menggunakan Tes Agilitas Illinois dengan cara berlari secepat cepatnya mengikuti alur tertentu. Tes dilakukan dua kali dengan waktu istirahat 3 menit dan diambil hasil yang terbaik.

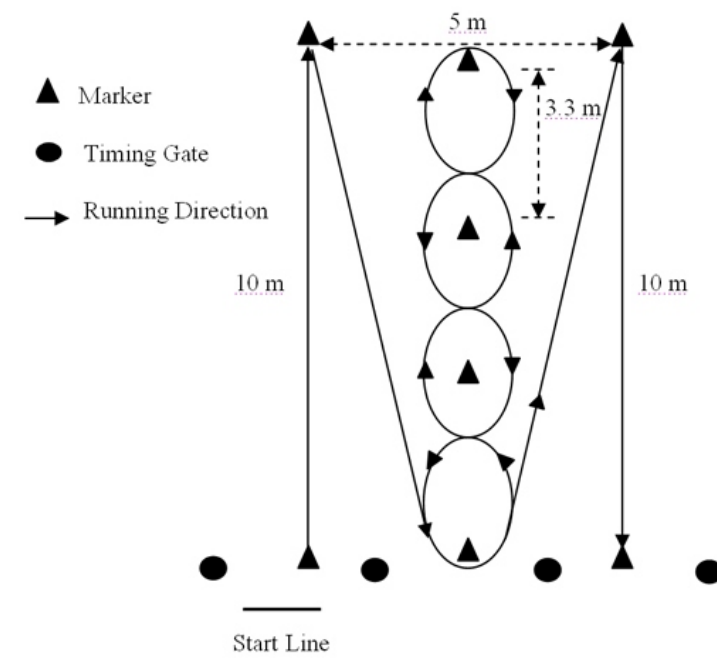

Gambar 1. Tes Agilitas Illinois 
Pemeriksaan daya ledak otot menggunakan jump meter digital (Gambar 2) dengan cara pelaksanaan responden berdiri tegak lurus diatas plate jump meter digital (md). Peneliti menekan tombol start dan ketika ada sinyal suara, responden melompat vertikal setinggi-tingginya. Hasil diukur dari ketinggian lompatan responden dan lamanya waktu saat telapak kaki lepas dari plate sampai mendarat pada plate. Hasil akan muncul di layar display. Responden melakukan lompatan sebanyak 3 kali pengulangan dengan jeda waktu 1 menit antar lompatan dan diambil hasil yang terbaik.

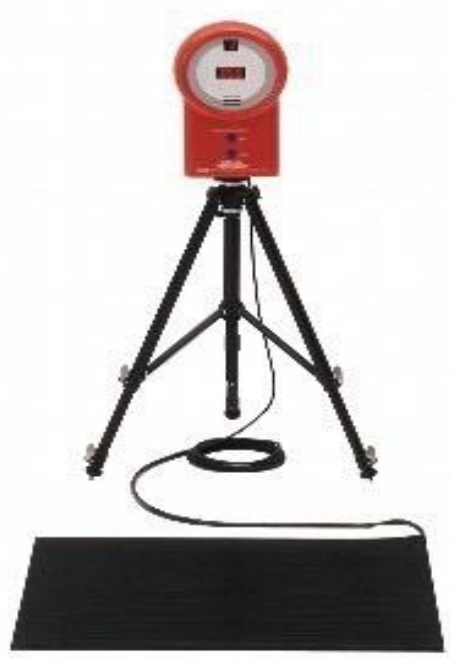

Gambar 2. Jump meter digital

Pemeriksaan kecepatan dilakukan dengan tes sprint 30 meter dan waktu berlari diukur dengan menggunakan stopwatch (Gambar 3). Kecepatan subjek didapatkan melalui perhitungan jarak dibagi waktu.

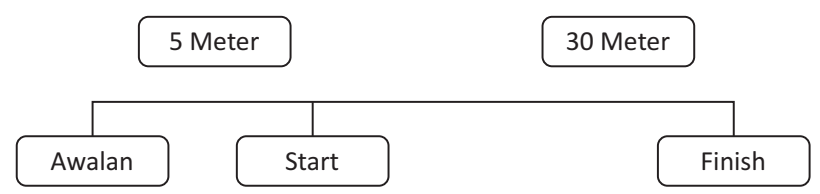

Gambar 3. Jarak lari pada tes sprint 30 meter

\section{Pemeriksaan Polimorfisme Gen ACTN 3}

Pemeriksaan polimorfisme gen ACTN3 pertama melakukan isolasi DNA sesuai dengan prosedur dalam Geneaid Genomic DNA mini kit, kemudian kadar DNA sampel diukur menggunakan spektrofotometer. Hasil isolasi DNA diletakkan pada tube PCR. Campuran reaksi PCR terdiri dari primer forward $1 \mu \mathrm{l}$, primer reverse $1 \mu \mathrm{l}$, PCR mix 12,5 $\mu \mathrm{l}, \mathrm{dH}_{2} \mathrm{O}$ steril $1 \mu \mathrm{l}$, DNA $1 \mu \mathrm{l}$. Program PCR yang digunakan adalah denaturasi awal $95^{\circ} \mathrm{C}$ selama 3 menit, denaturasi $95^{\circ} \mathrm{C}$ selama 30 detik, annealing $53^{\circ} \mathrm{C}$ selama 20 detik, extension $72^{\circ} \mathrm{C}$ selama 18 detik, dan final extension $72^{\circ} \mathrm{C}$ selama 10 menit. Produk PCR yang didapatkan pada 291 bp kemudian dipotong oleh enzim Ddel dengan komposisi enzim Ddel 0,5 $\mu$, buffer $2,5 \mu \mathrm{l}$, hasil PCR $12 \mu \mathrm{l}$, dan $\mathrm{dH}_{2} \mathrm{O} 10 \mu \mathrm{l}$ kemudian disimpan pada suhu $37^{\circ} \mathrm{C}$ selama 30 menit pada inkubator. Selanjutnya dilakukan proses elektroforesis, yaitu disiapkan gel agarose $2,5 \%$. Gel agarose dituangkan pada sumur agar dan dimasukkan comb. Gel agarose dipindahkan pada tangki elektroforesis setelah terbentuk agar. Proses elektroforesis dijalankan dengan tegangan 100 volt selama 50 menit. Dilakukan running gel. Diperoleh hasil Alel 577XX memiliki tiga fragmen (108, 97, dan 86 bp), alel 577RR memiliki dua fragmen (205 dan 86 bp), alel 577RX memiliki empat fragmen $(205,108,97$, dan 86 bp).

\section{Analisis Data dan Persetujuan Etik Penelitian}

Analisis data univariat dilakukan untuk melihat karakteristik subjek penelitian. Analisis bivariat dilakukan untuk melihat hubungan polimorfisme gen ACTN 3 dengan masing masing komponen biomotorik (kelincahan, daya ledak dan kecepatan). Analisis bivariat menggunakan uji ANOVA satu arah dengan uji alternatif Kruskall Wallis. Tingkat kepercayaan 95\% dan tingkat kemaknaan pada $p=0,05$. Penelitian telah mendapat persetujuan dari Komisi Etik Penelitian Kesehatan Fakultas Kedokteran Universitas Diponegoro/RSUP Dr. Kariadi Semarang (No. 041/EC/FK/RSDK/2013).

\section{HASIL}

Analisis univariat dilakukan untuk melihat karakteristik subjek penelitian seperti ditribusi polimorfisme gen ACTN 3 , data kelincahan, daya ledak dan kecepatan otot subjek penelitian.

Berdasarkan klasifikasi polimorfisme gen ACTN3 dibagi menjadi 3 jenis genotip yaitu RR, RX, dan XX. Berdasarkan Tabel 1 sebagian besar subjek penelitian memiliki genotip RX yaitu sebesar 54,9\% (45 responden) sedangkan jumlah genotip RR dan XX masing-masing 18,3\% (15 responden) dan $26,8 \%$ (22 responden).

Tabel 1. Distribusi karakteristik subjek penelitian berdasarkan polimorfisme gen ACTN3

\begin{tabular}{ccc}
\hline Kategori gen & Frekuensi (n) & Persentase (\%) \\
\hline RR & 15 & 18,3 \\
RX & 45 & 54,9 \\
XX & 22 & 26,8 \\
Total & 82 & 100 \\
\hline
\end{tabular}

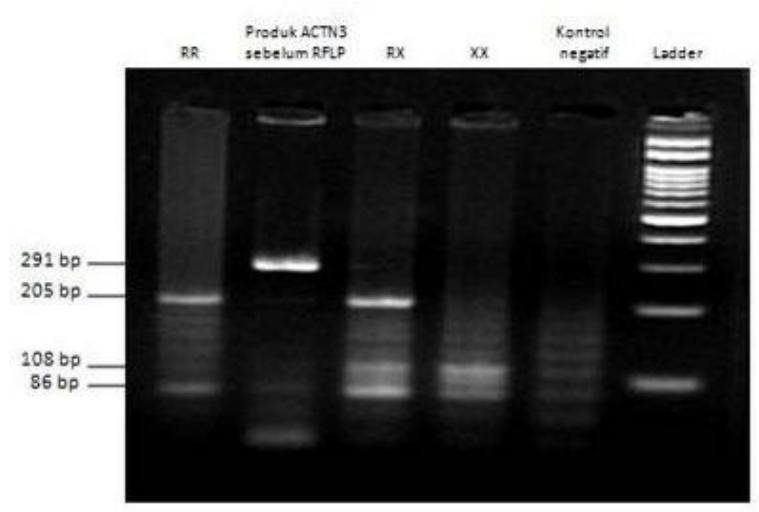

Gambar 4. Hasil PCR - RFLP 
Berdasarkan Tabel 2 dapat dilihat bahwa rerata kelincahan subjek penelitian adalah $18,16 \pm 1,59$ detik, daya ledak otot adalah $60,52 \pm 7,25 \mathrm{~cm}$ dan kecepatan adalah $7,67 \pm 0,56$ meter/detik.

Tabel 2. Komponen biomotorik subjek penelitian

\begin{tabular}{lccc}
\hline Komponen Biomotorik & Frekuensi (n) & Rerata & Simpang Baku \\
\hline Kelincahan & 82 & 18,16 & 1,59 \\
Daya Ledak & 82 & 60,52 & 7,25 \\
Kecepatan & 82 & 7,67 & 0,56 \\
\hline
\end{tabular}

Analisis data bivariat yang ditampilkan dalam Tabel 3 menunjukkan bahwa terdapat hubungan bermakna antara polimorfisme gen ACTN 3 dengan daya ledak otot $(p=0,027)$. Setelah dilakukan uji Post Hoc perbedaan bermakna terletak pada kelompok RR dan XX. Alel RR mempunyai rerata daya ledak terbesar $(63,67 \pm 5,52 \mathrm{~cm})$, sedangkan alel XX memiliki daya ledak terkecil $(57,77 \pm 6,55 \mathrm{~cm})$. Sedangkan analisis bivariat pada kedua komponen biomotorik yang lain menunjukkan tidak terdapat hubungan yang bermakna antara polimorfisme gen ACTN3 dengan kelincahan $(p=0,084)$ dan kecepatan $(p=0,507)$ pada atlet unit kegiatan mahasiswa (UKM) sepakbola di Universitas Jenderal Soedirman. Rerata kelincahan terbesar $(18,37 \pm 1,13$ detik) pada alel $X X$, sedangkan rerata kecepatan terbesar $(7,73 \pm 0,45 \mathrm{~m} / \mathrm{s})$ pada alel RR.

Tabel 3. Hasil analisis bivariat dengan One Way ANOVA

\begin{tabular}{lccc}
\hline $\begin{array}{l}\text { Komponen } \\
\text { Biomotorik }\end{array}$ & $\begin{array}{c}\text { Polimorfisme } \\
\text { ACTN 3 }\end{array}$ & Rerata \pm SD & $\begin{array}{c}\text { p } \\
\text { (Cl 95\%) }\end{array}$ \\
\hline Kelincahan & RR & $18,03 \pm 1,77$ & 0,084 \\
& RX & $18,10 \pm 1,73$ & $(17,81-18,51)$ \\
& XX & $18,37 \pm 1,13$ & \\
Daya Ledak Otot & RR & $63,67 \pm 5,52$ & 0,027 \\
& RX & $60,82 \pm 7,71$ & $(58,93-62,12)$ \\
& XX & $57,77 \pm 6,55$ & \\
Kecepatan & RR & $7,73 \pm 0,45$ & 0,507 \\
& RX & $7,71 \pm 0,57$ & $(7,54-7,79)$ \\
& XX & $7,54 \pm 0,59$ & \\
\hline
\end{tabular}

\section{DISKUSI}

Penelitian ini menunjukkan bahwa proporsi alel RX gen ACTN 3 paling banyak, yang kemudian dikuti alel XX dan terakhir alel RR. Penelitian yang dilakukan oleh Xiang (14) di China menunjukkan hasil proporsi yang serupa dimana genotip RX lebih besar dibandingkan dua genotip lain. Hasil ini juga sesuai dengan Goel and Balraj (15) yang menyatakan bahwa bangsa Asia memiliki genotip RX lebih banyak dibanding RR dan XX. Akan tetapi, hasil ini berbeda dengan penelitian Pimenta (16) yang memperoleh frekuensi genotip RR paling banyak pada atlet sepak bola sebagai subjek penelitiannya. Hal ini dikarenakan subjek penelitian Pimenta merupakan atlet sepak bola profesional sehingga kebanyakan aletnya sudah mempunyai gen RR dan kemudian masuk sebagai atlet professional. Atlet sepak bola sangat membutuhkan komponen biomotor yang dipresentasikan oleh genotip RR.

Berdasarkan klasifikasi tes Illinois, rerata kelincahan subjek penelitian tergolong baik (17). Subjek penelitian bukanlah atlet professional tetapi ternyata memiliki rerata yang lebih baik dari hasil penelitian lain pada sesama atlet yunior atau amatir. Sebagai contoh adalah penelitian yang dilakukan oleh Goedecke et al (18), menyatakan bahwa atlet sepak bola amatir memiliki waktu kelincahan lebih dari 20 detik sehingga dapat dimasukkan ke dalam kategori kurang. Rerata daya ledak subjek penelitian dan kecepatan sprint subjek penelitian juga termasuk dalam kategori baik. Walaupun demikian rerata skor kecepatan sprint pada penelitian ini lebih rendah dibanding dengan penelitian yang dilakukan oleh Delecluse (19) yang menghasilkan skor rerata kecepatan sprint sebesar $8,5 \mathrm{~m} / \mathrm{s}$ pada sprinttrained athletes. Perbedaan penelitian ini dengan Delecluse ialah atlet yang digunakan, dimana pada penelitian ini menggunakan atlet amatir sedangkan Delecluse menggunakan atlet profesional yang terlatih berlari sprint.

Hasil penelitian ini menunjukkan adanya hubungan antara polimorfisme gen ACTN 3 dengan daya ledak. Hal ini sesuai dengan penelitian yang dilakukan oleh Clarkson et al. (20) dan Delmonico et al. (21) yang menemukan adanya hubungan polimorfisme gen ACTN3 dengan performa atletik, dan genotip RR memberikan manfaat untuk performa daya ledak. Akan tetapi penelitian ini membuktikan tidak ada hubungan antara polimorfisme gen ACTN 3 dengan kelincahan dan kecepatan. Hal ini dimungkinkan karena alel RR gen ACTN 3 lebih berpengaruh terhadap aspek kekuatan daripada kecepatan. Akan tetapi referensi mengenai hal ini masil minimal. Segala aspek biomotorik yang mengandung komponen kekuatan dipengaruhi oleh alel RR gen ACTN 3. Dalam penelitian ini, gen ACTN 3 mempunyai hubungan dengan daya ledak karena daya ledak terdiri dari komponen kekuatan dan kecepatan. Akan tetapi tidak demikian dengan kelincahan, sebab walaupun kelincahan merupakan aspek yang tersusun dari daya ledak, tetapi komponen kecepatan lebih dominan pada aspek kelincahan ini.

Hasil serupa juga didapatkan Jung yang menemukan tidak ada hubungan antara polimorfisme gen ACTN 3 dengan kelincahan dan kecepatan pada olahraga bela diri (22). Akan tetapi hasil penelitian Jung menunjukan bahwa polimorfisme gen ACTN 3 alel XX memiliki resiko cedera lebih tinggi karena kelincahan dan kecepatan gerak yang lebih rendah dibandingkan alel yang lain (22). Berdasarkan hasil penelitian meta analysis oleh Alfred (23) juga membuktikan bahwa genotipe RR gen ACTN 3 dapat merepresentasikan kekuatan otot. Norman (24) menyatakan bahwa gen ACTN3 bukan merupakan faktor tunggal dalam pembentukan kecepatan. Faktor-faktor yang mungkin dapat mempengaruhi hasil penelitian ini ialah faktor status atlet (25), motivasi atlet, dan faktor jenis latihan atlet (20). Hal tersebut yang diduga mempengaruhi hasil penelitian ini yaitu bahwa populasi subjek penelitian yang merupakan atlet yunior atau atlet amatir yang tidak sepenuhnya sama dengan atlet elit atau atlet professional terutama dalam hal motivasi atlet. Faktor jenis latihan juga berpengaruh karena pada cabang olahraga sepak bola 
latihan kecepatan seperti sprint memang tidak mendominasi pola latihan fisik.

Gen ACTN3 merupakan gen yang mengkode protein $\alpha$ aktinin-3, protein sarkomer di serabut otot tipe cepat (10). Adanya protein $\alpha$-aktinin-3 meningkatkan fungsi serabut otot tipe cepat (12). Eynon (26) juga menyebutkan bahwa orang yang memiliki genotip RR memiliki jumlah serabut otot tipe II (cepat) lebih banyak sehingga bermanfaat untuk performa yang berkaitan dengan kekuatan otot, sedangkan orang yang memiliki genotip XX memiliki jumlah serat otot tipe I (lambat) yang lebih tinggi sehingga bermanfaat pada performa ketahanan, baik ketahanan otot maupun kardiorespirasi. Selain berpengaruh ke otot, polimorfisme gen ACTN 3 ternyata juga berpengaruh terhadap kadar testoteron. Ahmetov (27) menemukan bahwa polimorfisme gen ACTN 3 alel RR memiliki rerata kadar testoteron yang lebih besar dibandingkan alell yang lain. Testosteron memiliki efek anabolic dan menstimulasi

\section{DAFTAR PUSTAKA}

1. Anonim. Daftar Peringkat Dunia versi FIFA (Federation Internationale de Football Association) Edisi Februari 2013. (Online) 15 Februari 2013. h t t p : / / w w w. fifa.com / fifa-worldranking/associations/association=idn/men/index.h tml. [diakses tanggal 20 April 2013]

2. Bompa TO and Michael C. Periodization: Theory and Methodology of Training. Fifth Edition. Champaign: Human Kinetics; 2009.

3. Kusuma MNH, Dreisiglier T, and Portela J. Affecting Factors of Plyometric Exercise on Jumping Performance. Journal of Sports Medicine and Applied Physiology Germany. 2012; 52: 121.

4. Parahita A. Pengaruh Latihan Fisik Terprogram Terhadap Daya Tahan Otot pada Siswi Sekolah Bola Voli Tugu Muda Semarang Usia 9-12 Tahun. [Thesis]. Fakultas Kedokteran Universitas Diponegoro, Semarang. 2009

5. American Dietetic Association, Dietitians of Canada, American College of Sports Medicine, Rodriguez NR, Di Marco NM, and Langley S. American College of Sports Medicine Position Stand. Nutrition and Athletic Performance. Medicine and Science in Sports and Exercise. 2009; 41(3): 709-731.

6. Mayne I. Examination of the ACE and ACTN-3 Genes in UTC Varsity Athletes and Sedentary Students. [Thesis]. The University of Tennessee, Chattanooga. 2006.

7. Ma F, Yang Y, Li X, et al. The Association of Sport Performance with ACE and ACTN3 Genetic Polymorphisms: A Systematic Review and MetaAnalysis. Sport Performance and Human Genetic Polymorphisms. 2013; 8(1): 1-9.

8. Mac Arthur DG and North KN. ACTN3: A Genetic Influence on Muscle Function and Athletic Performance. Exercise and Sports Sciences Reviews. 2007; 35(1): 30-34.

9. Cieszczyk P, Sawczuk M, Karlowska AM, and Ficek K. ACTN3 R577X Polymorphism in Top-Level Polish Rowers. Journal of Exercise Science and Fitness. 2012; 10: 12-15. pertumbuhan otot dengan meningkatkan sintesis protein otot dan menghambat pemecahan protein melalui jalur mediasi ubiquitin (28). Beberapa penelitian membuktikan bahwa testoteron meningkatkan performa yang berkaitan dengan otot tipe cepat (28). Oleh karena itu, walaupun penelitian ini menunjukkan tidak ada hubungan antara polimorfisme gen ACTN 3 dengan kelincahan dan kecepatan, tetapi membuktikan bahwa semua komponen biomotorik yang diteliti (kelincahan, daya ledak dan kecepatan otot) memiliki rerata terbaik pada alel RR gen ACTN 3. Hal ini dikarenakan aspek biomotorik dalam penelitian ini didominasi dari kerja serabut otot tipe cepat.

\section{UCAPAN TERIMA KASIH}

Kami berterima kasih kepada PHK-PKPD (Program Hibah Kompetisi Peningkatan Kualitas Pendidikan Dokter) Kedokteran Universitas Jenderal Soedirman yang telah mendanai penelitian ini.

10. Massida M, Corrias L, Scorcu M, Vona G, and Calo MC. ACTN3 and ACE Genotypes in Elite Male Italian Athletes. Anthropological Review. 2012; 75(1): 51-59.

11. Moran CN, Yang N, Bailey ME, et al. Association Analysis of the ACTN3 R577X Polymorphism and Complex Quantitative Body Composition and Performance Phenotypes in Adolescent Greeks. European Journal of Human Genetics. 2007; 15(1): 88-93.

12. North K. Why is $\alpha$-Actinin-3 Deficiency So Common in the General Population? The Evolution of Athletic Performance. Twin Research and Human Genetics. 2008; 11(4): 384-394.

13. Paparini A, Ripani M, Giordan, GD, Santoni D, Piqozzi $\mathrm{F}$, and Romano SV. ACTN3 Genotyping by Real-Time $P C R$ in the Italian Population and Athletes. Medicine Science Sports Exercise. 2007; 39(5): 810-815.

14. Lanxiang He and Jie W. ACTN3 Polymorphism for Athletes of Han Nationality in Southwestern China. Journal of Chengdu Sport University. 2010; 2; 80-83, 88.

15. Goel H and Mittal B. ACTN3: Athlete Gene Prevalence in North India. Current Science. 2007; 92(1): 84-86.

16. Pimenta EM, Coelho DB, Veneroso CE, et al. Effect of ACTN3 Gene on Strength and Endurance in Soccer Players. The Journal of Strength and Conditioning Research. 2013; 27(12): 3286-3292.

17. Federation of International Lacrosse. Referee Fitness Testing Protocol. (Online) 2012. http://filacrosse.com/wpcontent/themes/sportedg e/downloads/FIL_Referee_Fitness_Testing_Protoco I.pdf. [diakses tanggal 18 Juli 2013].

18. Goedecke JH, White NJ, Chicktay W, Mahomed H, Durandt J, and Lambert MI. The Effect of Carbohydrate Ingestion on Performance during a Simulated Soccer Match. Nutrients. 2013; 5(12): 5193-5204.

19. Delecluse $C$, Roelants $M$, Diels R, Koninckx E, and Verschueren S. Effect of Whole Body Vibration Training on Muscle Strength and Sprint Performance in Sprint Trained Athlete. International Journal of 
Sports Medicine. 2005; 26(8): 662-668.

20. Clarkson PM, Devaney JM, Dressman HG, et al. ACTN3 Genotype is Associated with Increases in Muscle Strength in Response to Resistance Training in Women. Journal of Applied Physiology. 2005; 99: 154-163.

21. Delmonico MJ, Kostek MC, Doldo NA, et al. AlphaActinin-3 (ACTN3) R577X Polymorphism Influences Knee Extensor Peak Power Response to Strength Training in Older Men and Women. Journals of Gerontology. 2007; 62(2): 206-212.

22. Jung $\mathrm{H}$, Lee $\mathrm{N}$, and Park S. Interaction of ACTN3 Gene Polymorphism and Muscle Imbalance Effects on Kinematic Efficiency in Combat Sports Athletes. Journal Exercise Nutrition \& Biochemistry. 2016; 20(2): 1-7.

23. Alfred T, Ben-Shlomo $\mathrm{Y}$, Cooper R, et al. ACTN3 Genotype, Athletic Status, and Life Course Physical Capability: Meta-analysis of the Published Literature and Findings from Nine Studies. Human Mutation. 2011; 32(9): 1008-1018.
24. Norman $B$, Esbjornsson $M$, Rundqvist $H$, Osterlund T, Von Walden F, and Tesch PA. Strength, Power, Fiber Types, and mRNA Expression in Trained Men and Women with Different ACTN3 R577X Genotypes. Journal Applied Physiology. 2009; 106(3): 959-965.

25. AG Nur Signa, Candrawati S, dan HK Mohammad Nanang. Hubungan Polimorfisme Gen ACTN3 dengan Performa Otot pada Atlet UKM Sepak Bola Universitas Jenderal Soedirman. Jurnal Kedokteran Brawijaya. 2016; 29(1): 74-78.

26. Eynon N, Ruis JJ, Femia P, et al. The ACTN3 R577X Polymorphism across Three Groups Elite Male European Athletes. PLOS ONE. 2012; 7(8):1-7.

27. Ahmetov II, Donnikov AE, and Trofimov DY. ACTN3 Genotype is Assosiated with Testoterone Levels of Athletes. Biology of Sport. 2014; 31(2): 105-108.

28. Urban RJ. Growth Hormone and Testosterone: Anabolic Effects on Muscle. Hormone Research in Paediatrics Journal. 2011; 76(1): 81-83. 